\title{
SURFING ECONOMICS
}




\section{SURFING ECONOMICS}

Essays for the Inquiring Economist

HUW DAVID DIXON 


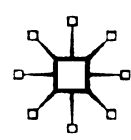

(C) Huw David Dixon 2001

All rights reserved. No reproduction, copy or transmission of this publication may be made without written permission.

No paragraph of this publication may be reproduced, copied or transmitted save with written permission or in accordance with the provisions of the Copyright, Designs and Patents Act 1988, or under the terms of any licence permitting limited copying issued by the Copyright Licensing Agency, 90 Tottenham Court Road, London W1P OLP.

Any person who does any unauthorised act in relation to this publication may be liable to criminal prosecution and civil claims for damages.

The author has asserted his right to be identified as the author of this work in accordance with the Copyright, Designs and Patents Act 1988.

First published 2001 by

PALGRAVE

Houndmills, Basingstoke, Hampshire RG21 6XS and

175 Fifth Avenue, New York, N.Y. 10010

Companies and representatives throughout the world

PALGRAVE is the new global academic imprint of

St. Martin's Press LLC Scholarly and Reference Division and

Palgrave Publisher Ltd (formerly Macmillan Press Ltd).

ISBN 978-0-333-76061-1 hardback

ISBN 978-1-349-87643-3 ISBN 978-1-137-04142-5 (eBook)

DOI 10.1007/978-1-137-04142-5

This book is printed on paper suitable for recycling and made from fully managed and sustained forest sources.

A catalogue record for this book is available from the British Library.

Library of Congress Cataloging-in-Publication Data

Dixon, Huw David.

Surfing economics : essays for the inquiring economist / Huw David Dixon p. $\mathrm{cm}$.

Includes bibliographical references and index.

ISBN 978-0-333-76061-1

1. Economics. I. Title.

HB171 .D639 2000

$330-\mathrm{dc} 21$

00-052456 
This book is dedicated to Carol, Clare and Adam 


\section{Contents}

Preface $\quad$ xi

Acknowledgements xiii

Introduction $\quad \mathrm{xv}$

PART I ECONOMICS AND THE MEANING OF LIFE

1 The Joy of Economics 3

1 Introduction 3

2 Infinity in a pencil 3

3 How we understand the economy: the principles that guide economists 5

4 What do economists argue about? 7

5 The limits of economics: are economists stupid? 12

6 The economy is intelligent 15

7 Conclusion 20

2 Equilibrium and Explanation $\quad 21$

1 The three crosses 23

2 Disequilibrium and equilibrium 38

3 Information and equilibrium 41

4 Time and equilibrium 48

5 Conclusion 52

PART II MAINLY MACRO

3 Of Coconuts, Decomposition and a Jackass:

The Genealogy of the Natural Rate 57

1 Introduction 57

2 The Classical dichotomy 57

3 Patinkin and full employment 59

4 Friedman and the natural rate hypothesis 63

5 Lucas-Rapping and the Lucas archipelago 65

6 Real business cycles 67

7 The NAIRU: unions and imperfect competition 67

8 An evaluation of the natural rate hypothesis 69

9 Conclusion 72

4 The Role of Imperfect Competition in New Keynesian Economics $\quad \mathbf{7 4}$

1 Introduction $\quad 74$ 
2 What's new pussycat? $\quad 74$

3 Imperfect competition for beginners: a microeconomic interlude

4 Of Keynes and the Keynesians $\quad 78$

5 Little and large: micro and macro $\quad 79$

6 Walrasian microeconomics and macroeconomics 80

7 Non-Walrasian microeconomics: neo-Keynesian macroeconomics $\quad 81$

8 Nominal rigidity 90

9 Envelopes, menu costs and nominal rigidity 91

10 Imperfect competition and the multiplier with flexible prices 97

11 The Cambridge soap: what might have been 105

12 Conclusion 106

5 New Keynesian Economics, Nominal Rigidities and Involuntary Unemployment $\quad 109$

1 Introduction $\quad 109$

2 The New Keynesian idea 110

3 Nominal rigidities before the New Keynesians 110

4 Nominal rigidities in New Keynesian models 112

5 Involuntary unemployment 113

6 New macroeconomics, new consensus 119

7 Conclusion: the lessons for methodology 120

\section{PART III MAINLY MICRO}

6 Oligopoly Theory Made Simple $\quad 125$

1 Introduction $\quad 125$

2 Non-cooperative equilibrium 126

3 Cournot and Bertrand equilibria with homogeneous products 129

4 Cournot and Bertrand equilibria with differentiated commodities 134

5 Precommitment: strategic investment and delegation 143

6 Competition over time 153

7 Conclusions 159

7 Some Thoughts on Economic Theory and Artificial Intelligence 161

1 Introduction 161

2 Orthodox economic rationality: rationality without reasoning 162

3 Complexity and artificial intelligence 166

4 Reasoning as precommitment: an example 173

5 Conclusion $\quad 175$

8 Donut World and the Duopoly Archipelago: Social Learning and the Evolution of Competition 
2 Social learning: from Antoine Augustin Cournot to John Maynard Smith

3 Social learning in human societies: Gabriel Tarde

4 Economic natural selection: keeping up with the Joneses

5 Conclusion: how economists can get smarter by making agents dumber? 


\section{Preface}

Economics is a social process. Economics is taught in schools and universities; economic research is written, some of it published in books and learned journals; in the public and private sectors economists advise on a variety of issues (sometimes giving good advice, sometimes bad!); economics graduates go on to prosper in a variety of professions, the ideas they have learned influencing the way they think; economic ideas, often in distorted caricatures, circulate around society in newspapers and political debate. Economics is a social phenomenon, it is how society thinks about the economy in which they find themselves. Somewhere within this social process you will find me: lecturing, marking exams, writing research papers, submitting them to journals, refereeing papers submitted by other people, advising government, presenting my research at conferences and seminars. Like any professional or academic economist, I am part of this big show, this evolving monster, sailing through the mist of history to goodness knows where.

We are all part of a process by which human society comes to understand the economy and indeed itself. Much of this 'thinking' goes on behind closed doors between consenting adults. The closed doors are not so much physical, but social. Academic economists write and speak in a special language that is largely incomprehensible to non-economists: it uses lots of specialist jargon and is often mathematical. Indeed, the assumptions made by economists might look bizarre and fantastic to any but the initiated: people live forever, can see into the future with perfect foresight, adopt elaborate statistical methods and live in highly stylised worlds. Indeed, with increasing specialism in economics, there is even a growing gap between what is treated as standard in one part of economics and others.

There is a danger that the world of academic economics will fail to communicate with the rest of society. This would be a real shame: the ideas, concepts and tools of economics deserve a wider audience. It is our duty as economists to convince and engage with others, be they students, government policy-makers or the general public.

The essays in this book are certainly academic in nature: indeed, some have been published in academic journals and learned volumes; and some chapters contain equations and diagrams that may baffle the layperson. However, they are aimed to communicate ideas in a simple and direct way to the student of economics who is interested in thinking a bit more about economics and doing more than just mechanically learning what is in textbooks. I very much hope that this collection will play a small but useful and enjoyable part in the social process of economics.

Huw DAvid Dixon 


\section{Acknowledgements}

The chapters in this book have been written over a long period. I would like to thank my wife Carol for putting up with me throughout this period: being married to an academic and (even worse) an economist deserves a medal. I would also like to thank the various generations of students at Birkbeck College, Essex and York Universities on whom earlier versions of most of these chapters (or parts thereof) were tried out. Teaching is always a good way to make your own thoughts clear, and I have benefitted from much valuable feedback. Lastly, I would like to thank the publishers for nudging me repeatedly to get the book finished.

I would like to thank the following publishers for giving me permission to reprint the various chapters in this collection, reproduced with minor amendments: Blackwells for permission to reprint 'Equilibrium and Explanation', in J. Creedy (ed.), The Foundations of Economic Thought, Blackwell 1990, chapter 13, pp. 356-94. Cambridge University Press for permission to reprint 'Of Coconuts, Decomposition, and a Jackass: A Geneology of the Natural Rate of Unemployment', in R. Cross (ed.), The Natural Rate 25 Years on, Cambridge University Press 1995, pp. 57-74. Edward Elgar for permission to reprint 'Some Thoughts on Artificial Intelligence and Economic Theory', in S. Moss and J. Rae (eds), Artificial Intelligence and Economic Analysis, Edward Elgar 1992, pp. 131-154; 'Reflections on New Keynesian Economics; the Role of Imperfect Competition', in H. Vane and B. Snowden (eds), Reflections on Modern Macroeconomics, Edward Elgar 1998, pp. 158-203. Pearson Group for permission to reprint 'Oligopoly Theory made Simple', in S. Davies et al. (eds), The Economics of Industrial Organisation, Longmans 1988, chapter 4, pp. 127-63. Taylor \& Francis Ltd for permission to reprint 'New Keynesian Economics, Nominal Rigidities and Involuntary Unemployment', Journal of Economic Methodology, 1999, vol. 6, pp. 221-38<http://www.tandf.co.uk/journals/.htm>. 


\section{Introduction}

I remember sitting in my fourth-floor office on a sunny day. I was a young lecturer (assistant Professor in US terms) at Birkbeck College in London, busy teaching and establishing my research career. The phone rang, and I heard the voice of my friend Steve Davies asking me if I would like to write a chapter on oligopoly theory for a book he was writing on Industrial Organisation. Well, yes, this seemed like an excellent opportunity. I was teaching a course on IO for the graduate students at Birkbeck, and it was already apparent to me that there was a real gap in what was going on in IO. On the one hand, the real action was happening in conferences and seminars around the world: researchers were busy talking to each other and developing many new and interesting ideas (the early mid-1980s were an exciting time for IO!). Much of this could be read about, but only in a highly technical and condensed form found in academic journals; not really suitable for students. On the other hand, there were a variety of textbooks that tended to rehash the same old things that other people had done before. However, what I wanted to get over was the truly exciting and fundamental ideas that were being developed, but in a simple form. Well, I only had a few weeks to write the chapter (six weeks I seem to remember), so I just developed my lecture notes. The end result was 'Oligopoly Theory made Simple' (1988). What I tried to achieve was to communicate the fundamental ideas in a rigorous but simple manner, so that people reading the chapter would know what was going on at the frontier of research: maybe not the details of course, it was the spirit that mattered.

I could tell a similar story for most of the chapters in this book. In each case, an invitation by letter or phone (and later still by e-mail) provided me with the opportunity to communicate something I felt passionately about. John Creedy asked me to write about the concept of equilibrium: the end result was 'Equilibrium and Explanation' (1990). This reflects very much my thoughts arising out of various lectures: at Birkbeck College again on general equilibrium theory and introductory micro and macro. Also, my interest in philosophy found an outlet (I had read economics and philosophy as an undergraduate at Balliol College Oxford). Rod Cross asked me to write about the Natural Rate: this was a real joy, because I felt that the textbook treatment was so bad! You can read the end result in 'Of Coconuts, Decomposition, and a Jackass: The Genealogy of the Natural Rate' (1995).

Two of the chapters have arisen from academic conferences. The first was an excellent conference organised by Scott Moss at Manchester on Artificial Intelligence and Economics, with a mixture of computer scientists, economic theorists and management scientists. This conference made a big impact on me. As a student at Balliol, I had always been suspicious of the assumption of 
optimising behaviour, becoming a great fan of the writings of people like Herbert Simon, Brian Loasby, George Shackle and Axel Leijohufvud (amongst many others!). However, as a doctoral student I set to learning all of the technical stuff and spent more time reading Apostol's Real Analysis than worrying about the meaning of it all. However, whilst I went with the flow and adopted the necessary conventions for professional success, I never forgot what I had known. The paper that resulted was 'Some Thoughts on Economic Theory and Artificial Intelligence'. The other conference was organised by Roger Backhouse and Andrea Salanti in the beautiful city of Bergamo. This gave me the chance to write a paper that really got to the bottom of what was wrong with the competitive model of the labour market and why a model of involuntary unemployment was so central to any reasonable macroeconomic theory. 'New Keynesian Economics, Nominal Rigidities and Involuntary Unemployment' is the only chapter in this volume that has been published in an economic journal.

None of the chapters mentioned previously were written explicitly for undergraduate students. Things changed when around 1997 Brian Snowden and Howard Vane invited me to write a chapter on new Keynesian economics for an undergraduate text. In 'The Role of Imperfect Competition in New Keynesian Economics', I took part of my then graduate lectures at York and made them simple, trying to get the basic ideas over without too much technicality. As always, what is important is the conceptual framework, not the equations! Lastly, there are the two chapters written exclusively for this book. In 'The Joy of Economics', I bring out the big picture and explain why we should not think of economics as a dismal science. There are some really interesting issues and questions underlying economics which are often left out as lecturers and examiners tend to concentrate on the equations. Lastly, there is 'Donut World and the Duopoly Archipelago'. This is the result of the process started at the Manchester conference. The 1990s were an exciting time for the issues for bounded rationality and social learning. They had a real renaissance in mainstream economics: particularly game theory, behavioural finance and experimental economics. These ideas deserve to be made much more widely available to undergraduates, to serve as an antidote to the otherwise relentless and rather far-fetched notions of rationality that predominate in undergraduate textbooks. As I argue in 'Some Thoughts on Artificial Intelligence and Economics', whilst the standard model of rationality might be a useful tool and a good approximation in certain cases, it should not be the only model we use to the exclusion of all others.

Lastly, a couple of comments on the style of the book. I have left the chapters largely unchanged except for introducing uniformity in terms of numbering of figures and so on. This means that the chapters are completely self-contained: each one can be read in complete isolation from the others. I have added cross references, but these are only very general. One result of this is that there is some repetition. However, the repetition serves a purpose: the same material is approached from different directions, giving it a different perspective each time. Thus, for example, the Cournot model of oligopoly appears in three chapters: in 
'Equilibrium and Explanantion' it is explored as an equilibrium concept; in 'Oligopoly Theory Made Simple' it is very much worked out as a practical modelling tool; in 'Donut World and the Duopoly Archipelago' it is treated as a social learning model and linked to evolutionary models. Finally, if you read these chapters you will see the evolution of my English style over the last 16 years! This has changed considerably. Perhaps the main shift has been towards a simpler world English. Over the years, I have become much more sensitive to the knowledge that most people reading my work will not have English as a first language: writing for a native British or American reader is a different exercise from writing for a Chinese or Turkish reader. A large vocabulary or common concepts cannot be expected. However, since my prime concern has always been towards clarity and content rather than style, I do not see this as something bad. Lastly, I am an inveterate and incorrigible infinitive splitter. For those poor souls who are still under the misapprehension that there is anything wrong in this, I would direct you to the excellent discussion in The Cambridge Encyclopaedia of the English Language by David Crystal.

It is very much hoped that these essays will be able to accompany a student of economics through his or her studies. The 'level' of the chapters differs in terms of content and technical know-how required and the exact place in an undergraduate programme will differ from country to country and the exact nature of the degree programme. However, as a general rule, I think that the chapters can be divided into two by the earliest point at which they can be most usefully read.

The first group are clearly appropriate for students who are studying intermediate macro or micro texts: these are all of the chapters except Chapters 6 and 7, which are more appropriate for students who have mastered the intermediate micro course and are specialising in microeconomics. Some chapters are a mixture: for example, 'Equilibrium and Explanation' in the early sections is suitable for intermediate students, but contains some material (on information and signalling) that is often not dealt with until later. Likewise, whilst 'Donut World' is at an intermediate level, the 'Duopoly Archipelago' is more advanced.

These chapters will, hopefully, have something useful for economists at all levels. I very much hope that you enjoy reading them as much as I did writing them. 